ad 4. Aan te houden 25 exemplaren, verder als sub 1.

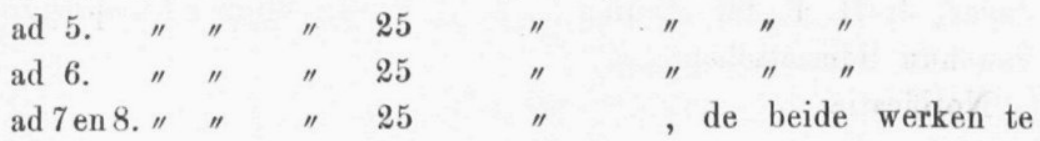
zamen verkrijgbaar te stellen voor f $2 .-$.

ad 9. Aan te houden 25 exemplaren, verder als sub 1.

ad 10. " " " 25 " "

ad 11. " " " 50 " " " " "

ad 12. " " " 25 " " "

ad 13. " " " 25 " "

ad 14. " " " 50 " "

ad 15. " " " 50 " " "

ad 16. " " "

ad 18. " " " 25 " " "

terwijl de beslissing omtrent de verkrijgbaarstelling tegen lageren prijs van het werk sub 17 genoemd tot later wordt uitgesteld.

Voorts wordt bepaald dat de vergoeding voor vracht en onkosten, door de leden bij hunne anvraag om toezending van een of meer der genoemde werken over te maken, zal bedragen f 0.25 per deel voor de leden in Nederland; f 0.50 per deel voor de leden in Indië.

De vergadering wordt gesloten.

\title{
367e BESTUURSVERGADERING.
}

18 JANUARI 1896.

Aanwezig zijn de HH. Kern (Voorzitter), van Limburg Stirum, Martin, van den Berg, Spanjaard, Poensen, J. H. de Groot (Penningmeester) en Kielstra (Secretaris).

Afwezig, met kennisgeving, de HH. Pijnacker Hordijk (Onder-Voorzitter), van der Lith en J. J. M. de Groot.

De notulen der vorige vergadering, van 21 December 1895, worden gelezen en goedgekeurd. 
Ingekomen zijn berichten van de HH. J. de Groot, J. W. Jäger, J. H. F. ter Meulen en B. R. F. van Vlijmen tot opzegging van hun lidmaatschap.

Notificatie.

Ingekomen zijn berichten betreffende het overlijden der leden Dr. F. A. C. Dumontier, A. J. Spaan en J. J. van Santen.

De Voorzitter wijdt een woord van hulde aan hunne nagedachtenis, in het bijzonder aan die van eerstgenoemde, die in vroegere jaren deel uitmaakte van het bestuur van het Instituut, en aan die van den heer Spaan, die midden uit zijn werkzaamheden ten bate der Indologische wetenschappen werd weggerukt.

De Secretaris deelt mede dat het lid C. B. van de Wal Duyster de uit de bibliotheek sedert Aug. en Sept. 1894 geleende boeken niet terugzond en op aanmaning deswege niet antwoorddc. Hij heeft hem den $7^{\text {en }}$ dezer, per aangeteekenden brief aan zijne verplichtingen herinnerd en daarop van zekeren heer Walch bericht ontvangen dat de heer van de Wal sedert geruimen tijd buiten 's lands is voor zijne gezondheid, en dat intusschen een gedeelte der boeken wordt teruggezonden. Doch er is sedert niets ontvangen, zoodat de Secretaris zich verplicht acht, den heer Walch nadere opheldering te vragen.

Goedgekeurd

Van de Société Imperiale Russe de Géographie is bericht ontvangen dat zij den $2^{\text {en }}$ Februari a. s. haar 50jarig bestaan zal vieren.

Wordt besloten, haar een brief te doen geworden tot aanbieding der gelukwenschen van het Instituut.

De Penningmeester brengt ter tafel zijne rekening en verantwoording van het jaar 1895, welke staande de vergadering wordt nagezien door de HH. Spanjaard en van den Berg.

Deze verklaren haar in volkomen orde bevonden te hebben.

Wordt besloten, haar thans ingevolge art. 4 van het Huishoudelijk Reglement in handen te stellen van twee gewone leden, waartoe zullen worden uitgenoodigd de HH. W. P. Groeneveldt en P. H. van der Kemp. 